ks. Czesław S. Bartnik

Katolicki Uniwersytet Lubelski Jana Pawła II

0000-0001-9791-0219

DOI: $10.15290 /$ std.2018.04.07

\title{
ZNACZENIE OSOBY W TEOLOGII
}

\section{THE MEANING OF A PERSON IN THEOLOGY}

Philosophy and theology were generally of a rhetorical character (the object is treated as a thing), even personal beings like man, God - are treated as objects, which is supposed to convey the objectivity of the approach. The author of the article changes this approach by leaving the category of a person and taking everything in the aspect of personalism as a system. In the current general understanding, a person in the concept of Boethius rather means man as a rational nature. Personalism assumes that a person is a subsistence in the way of someone in relation to the whole reality or a subsistent substance subsisting with a unique self or subsisting as someone in the nature of being. Philosophy and theology as systems come not from philosophical principles, but from the fact of a person as a central reality. The person is the highest kind of being, beyond which there is no higher, that is why God without a person would be infinitely lower than man. And every element of reality becomes understandable in the relationship between the human person and the divine person.

Key words: person, person sphere, soul, social person, personalism.

\section{Ogólna sytuacja intelektualna}

Bardzo liczni dzisiejsi uczeni i myśliciele, głównie ateizujący, postmoderniści, scjentyści, neopozytywiści, postmarksiści i skrajni liberałowie są przeciwni prawdzie bezwzględnej, pierwszym zasadom bytu i myślenia i niemal wszystkim klasycznym wyższym wartościom w dotychczasowym ujmowaniu, 
a także często odrzucają pojęcia duszy, osoby i Boga. Na miejsce kierunków maksymalistycznych w filozofii przyjmują co najwyżej kierunki minimalistyczne, fragmentaryczne i relatywistyczne. Szerzy się ucieczka od ontologii naturalnej ku technologicznej i w konsekwencji ku wirtualności. W humanistyce jawi się kult chaosu, pesymizm, zwrot ku antywartościom i lęk przed myślą mocną i głęboką. Sytuacja w naukach i w filozofii wpływa także coraz mocniej i na teologię, i w ogóle na myśl religijną.

\section{Sytuacja poznawcza „osoby”}

Ogólna sytuacja filozoficzna i naukowa rzutuje mocno na prawdziwościową sytuację bytu i pojęcia osoby. Przede wszystkim rysuje się ostra konfrontacja między filozoficznym (metafizycznym) pojmowaniem osoby ludzkiej a naukowym traktowaniem psychiki człowieka, co określa się coraz szerzej jako kogniwistykę empiryczną. W ostatnich latach nastąpił ogromny wysyp prac i ujęć tej problematyki, że można się zgubić. Mocne i głębokie ujęcie osoby występuje nadal w metafizyce klasycznej, głównie arystotelesowsko-tomistycznej.

Osobę charakteryzuje się tam jako samodzielnie istniejącą substancję (metafizycznie rozumiany podmiot) o naturze rozumnej (racjonalnej), zdolną do realizacji wyższych funkcji umysłowo-poznawczych, takich jak: tworzenie pojęć i abstrakcyjne myślenie, formułowanie sądów, wnioskowanie, zdolność do inteligentnego ujęcia pierwszych zasad myśli i bytu, racjonalne podejmowanie decyzji czy (duchowa) miłość ${ }^{1}$.

Tymczasem kogniwistyka naukowa wiąże po prostu wysokie funkcje naukowe z samym mózgiem, ze strukturami mózgopodobnymi i robotyką kognitywną. I tu jest problem. Kognitywiści naukowi zarzucają filozofom, że zbyt dużo chcą wyczytywać ze zjawisk empirycznych, a filozofowie zarzucają kognitywistom empirycznym i czysto zjawiskowym, że są słabi i ograniczeni intelektualnie. Przy tym niektórzy filozofowie tworzą definicje osoby niedorzeczne, z kolei kognitywiści posługują się pojęciami filozoficznymi, a biorą je za empiryczne. Jedni chcą tylko pewnej rewizji klasycznych pojęć jak: umysł, świadomość, jaźń, wolna wola i właśnie osoba (np. R. Poczobut), inni chcą te pojęcia w ogóle odrzucić. A wreszcie nie brak i takich, którzy po prostu uważają, że w rzędzie Naczelnych (małpiatki, małpy, hominidzi) człowiek nie jest wyjątkiem, jeśli chodzi o budowę i funkcje organizmu, a także o strukturę umysłu, zdolności poznawcze, procesy myślowe, komunikację wzajemną, pamięć, wytwarzanie narzędzi i planowanie przyszłości².

\footnotetext{
1 R. Poczobut, Kategoria osoby w kontekście kogniwistyki, „Ethos” 20(2016) nr 4, s. 133-151.

2 Por. M. Trojan, Na tropie zwierzęcego umystu, Warszawa 2013.
} 
Nie należy jednak rezygnować z żadnej z dwu dróg poznania i ich wyniki należy uniesprzeczniać. Pierre Teilhard de Chardin (+1955) ciekawie przypisywał naczelnym, a nawet i innym ssakom „świadomość prostą” (la conscience simple), a człowiekowi „świadomość refleksyjną” (la conscience réfléchie), która w ewolucji jest już mutacją duchową, a następnie przybiera postać „wspól-refleksji” społecznej (la conscience co-réfléchie). Uważam, że owe, wymienione zjawiska psychiczne nie są strukturami osoby, ale raczej tylko jej funkcjami, związanymi z organizmem materialnym. Osoba zaś jest w swej istocie misterium metafizycznym i ontycznym ostatecznym podmiotem. Nie wolno np. świadomości uważać za strukturę osoby, bo człowiek, który na pewien czas stracił świadomość przestawałby także być osobą.

\section{„Definicja” osoby}

Ścisłej definicji osoby nie ma, bo nie ma rodzaju, jest bytem prapierwotnym, najwyższym z możliwych, natomiast jest jej opisanie. W językach biblijnych określano ją przez jej wyraz na twarzy, mianowicie przez „oblicze”. Szeroko rozpowszechniona do dziś filozoficzna, typu arystotelesowskiego, definicja Anicjusza Manliusza Boethiusa (+ok. 524): Persona est naturae rationalis (vel rationabilis) individua substantia („Osoba jest indywidualną substancją natury rozumnej”) - to raczej - według mnie - stare określenie człowieka: dzoon logikon, animal rationale, które nie ma niepowtarzalności każdej jednostki. Dlatego zaproponowałem określenie: Ego subsistens in natura rerum („Ja” subsystujące w łonie rzeczywistości) lub aliquis subsistens in natura rerum (subsystujący w łonie rzeczywistości jako „ktoś”). Jest to zatem substancja, czyli bytowość wyodrębniona, ale subsystentna, tzn. w sobie, lecz z prymatem istnienia, co podkreślało średniowiecze, na czele ze św. Tomaszem. A indywidualności nie oddaje w pełni jednostkowość, bo jednostki danego gatunku są zawsze takie same, natomiast niepowtarzalność absolutną daje dopiero na dobre odkryte w nowożytności, metafizyczne „Ja”, które zwiera ciało i duszę w jedyną imienną i niepowtarzalną istotę osobową. In natura rerum oznacza, że osoba nie jest abstrakcją i czystą osobnością, lecz ma związek z całą rzeczywistością.

Wielu filozofów i teologów kończy swoje rozważania na przedstawieniu pojęcia osoby. Nazywa się ich personalistami, ale w całości niesłusznie, bo oni uczą tylko, że człowiek jest osobą, a w sensie systemowym mogą być tomistami egzystencjalistami, czy nawet neomarksistami. Raczej więc tylko uprawiają personologię. Przy czym dziś wielu nie przyjmuje realnej bytowości osoby, widząc osobę tylko jako ideę, abstrakcję, stan, funkcję psychoorganiczną itp. I dlatego trzeba nam dowodzić bytowego istnienia osoby, co mieści się w terminie „subsystencji”, czyli realnej samoistności i oznacza coś więcej niż „dusza”, którą 
to liczni tomiści utożsamiają z osobą. Wielu też naszych uczonych krępuje się dowodzić realnego istnienia duszy i osoby, obawiając się opinii, że są zacofani. Tymczasem podstawowe prawdy muszą być ciągle głoszone i dowodzone. Trzeba choćby przypomnieć, że nasz wybitny filozof, Roman Ingarden dowodził $\mathrm{w}$ trzech tomach, że świat naprawdę istnieje ${ }^{3}$. W każdym razie personalizm jako system musi być realistyczny, czyli musi w swej całej wizji świata wychodzić $z$ bytowej realności osoby.

Nauki na Zachodzie ponad 2 tysiące lat traktowały o rzeczywistości jako o rzeczach, przedmiotach i anonimowej bytowości, nawet i na człowieka i na samego Boga patrzono w zasadzie pod kątem reistycznym, przedmiotowym i mówiono, że nauki mogą być „obiektywne”, tylko wtedy, gdy traktują o rzeczach. Wyjątek stanowiły niektóre działy teologii chrześcijańskiej np. mistyka. A naukowy system personalizmu rozciąga się także na cały świat „subiektywny”, podmiotowy, na całą głębię świata osoby i na całą długość promienia działań osoby, łącznie z dzisiejszym światem społecznym i technologicznym. W rezultacie personalizm wiąże świat rzeczy i świat subiektywny w jedną integralną całość. „Ja” ludzkie jest w relacji do całej rzeczywistości, a więc personalizm musi być też uniwersalny.

Przy czym polski termin „osoba” nie łączył się, przynajmniej w początkach, $z$ "osobnością”, lecz raczej wywodził się z indoeuropejskiego „se”, po polsku gwarowe „se”, „sobie”, „się”, „w sobie”, co oznaczało raczej wnętrze człowieka, „jaźñ", czynności zwrotne.

A wreszcie osoba ma przedziwne odniesienia do całej rzeczywistości pozapersonalnej. Nie sposób aż tego opisać. Jest ona concretum universale i universale concretum, czyli konkretem zuniwersalizowanym wobec wszechbytu i jednocześnie uniwersalnością świata skonkretyzowaną do jednego świata osobowego. Jest bytem najdoskonalszym, centrum wszechbytu, jest paradygmatem rzeczywistości w ogóle i poznania. Poznany świat przez osobę dodaje mu jakiś aspekt realności (św. Tomasz z Akwinu). Jest najwyższym sensem świata i chroni świat materialny przed anonimowością i bezimiennością. Jest na ziemi twórczynią prawdy, dobra, piękna, miłości, mądrości, wolności, sprawiedliwości. Buduje nowe światy według swoich zamysłów. Żyjąc w Osobie Chrystusa jest rekapitulacją i streszczeniem całej historii ziemskiej i zbawczej (KDK 38). Osoba pokonuje triumfalnie nicość z pomocą Osób Boskich.

Trzeba zatem powiedzieć, że osoba nie jest tylko teatralną rolą człowieka na świecie, ani zresztą jakimś prostym składakiem ciała, psychiki i duszy, lecz ma bytowość najbardziej realistyczną, najwyższego rodzaju i stanowi największe misterium.

Spór o istnienie świata, 3 tomy, Kraków - Warszawa 1947-1948, 1981. 


\section{Teologia personalistyczna}

Czy zatem teologia katolicka była od zawsze - można powiedzieć - personalistyczna? Absolutnie tak! Tylko, że w ujęciach systemowych, przyjmujących klasyczne greckie rozumienie nauki raczej reistyczne, rzeczywistości osobowej formalnie nie rozwijano. Kiedy zaś świat osoby weźmie się za punkt wyjścia dla konstruowania całej teologii oraz całego systemu, to znaczenie kategorii osoby okazuje się niezwykle twórcze i dopełniające teologię klasyczną.

Po prostu bez osoby nie byłoby ani Boga, ani religii. I bez zdeklarowanej kategorii osobowej, czy to pojęciowo i świadomie, czy choćby implicite nie ma chrześcijańskiej teologii. Oto niektórzy pseudouczeni powiadają, że Bóg jest bezosobowy. Tymczasem, gdyby tak było, to Bóg byłby czymś nieskończenie niższym niż człowiek jako osoba. Bóg byłby rzeczą, a osoba jest najdoskonalszym bytem z możliwych, zresztą czegoś doskonalszego istotowo nie można sobie nawet wymyślić, jest natomiast tylko ontyczna hierarchia osób: człowiek, anioł, Bóg.

W wielkich religiach świata istotną rolę odgrywało pojmowanie Boga: politeizm, henoteizm, monoteizm. Dlaczego Opatrzność dopuściła cały proces kształtowania się tych obrazów i ujęć? Otóż Bóg pojmowany jako jeden jedyny, a osobowy, byłby według ludzkich pojęć absolutnym egoistą: żyłby tylko sobą, myślałby tylko siebie, jak uczył Arystoteles, kochałby tylko siebie i mówiłby tylko do siebie i nie mógłby być stwórcą świata. Według politeistów bogów osobowych jest wiele, to słuszne, bo osoba boska nie może być solipsystyczna, lecz społeczna, ale wielość rozbija ich boskość, a na pierwsze miejsce wysuwa świat bezosobowy. Toteż po tysiącleciach w niektórych wielkich religiach zaczęły się pojawiać obrazy jednoczące: bądź, to w postaci henoteizmu (na początku i w Izraelu), bądź w postaci „trójc” wielkich bogów. W rezultacie można wnosić, że Opatrzność przygotowywała ludzkość na przyjęcie Objawienia Chrystusowego, że jest Jeden Bóg w Trzech Osobach. I w Trójcy każda osoba jest osobą dzięki pełnemu odniesieniu do dwu innych. I razem tworzą niewypowiedziany Byt osobowy. Oczywiście osoba w Bogu jest nieporównywalna do osoby ludzkiej.

Ale idźmy dalej! Bóg Trójmiłosny ma miłość rozlewną, nie chce być Bożą Trójmiłością tylko dla siebie. Postanowił powołać do istnienia istoty, które obdaruje miłosnym darem obrazu i podobieństwa swojej osoby. Mamy zatem obraz i podobieństwo Boże nie tylko w rozumie, woli, twórczości, postawie, lecz pełne i najgłębsze: w osobie. Z kolei nie mógł zaistnieć, stworzony, czy powołany do Boga tylko jeden człowiek - niektóre religie przyjmowały na początku człowieka „megantropa” (np. mazdaizm, wedyzm, manicheizm) - bo byłby także potworem i samotnikiem. Człowiek został powołany jako osoba, tzn. w koniecznej korelacji do Stwórcy i do 
innych osób ${ }^{4}$. Ludzkość zaistniała zatem na wzór trynitarny: ojciec, matka, dziecko, i to nie tylko biologicznie, jak w świecie zwierzęcym, lecz osobowo. W konsekwencji i człowiek religijny nie może być absolutnym samotnikiem, lecz musi tworzyć społeczność, Kościól, społeczne Ciało Chrystusa, i to znów na wzór osobowy, bo jak uczył św. Augustyn - Kościół jest nie tyle instytucją, co raczej pewnego rodzaju osobą społeczną .

I istotną strukturę osoby ludzkiej stanowi jej konieczna i spełniająca ją relacja do Osób Boskich. A dla człowieka realizuje się w łonie medialnego charakteru rzeczywistości stworzonej, subosobowej. Można powiedzieć, że świat jest stworzonym, przebogatym dwubiegunowym językiem między Osobami Boskimi a ludzkimi. Bóg mówi do osoby ludzkiej istnieniem, darem bytu, rzeczami, dziejami, naturą, wszechświatem, najbardziej personalistycznie słowem szczególnej miłości, która daje wieczność, a mianowicie objawieniem historycznym. Człowiek jako osoba musi ten język miłości świadomie i też z miłością przyjmować, odczytywać i językiem osobowym odpowiadać. Dzięki temu świat nie jest anonimowy i bezsensowny. Osoby nadają mu sens i imię. Cała ludzkość od początku odczytywała świat antropicznie, a nawet personalistycznie. Cały sens świata jest w perspektywie osobowej: mógł zaistnieć tylko dzięki osobie - Bożej i tylko dla osób, w których się spełnia. Bowiem tylko osoba może pokonać nicość na zawsze. Toteż nawet w ujęciu jak najbardziej naturalnym osoba ma coś $z$ semantyki religijnej. Może więc i trochę słusznie ateiści tak stronią od słowa „osoba”. Konsekwentny ateista godzi bowiem w osobę Boga, ale także w osobę człowieka i w całą rzeczywistość, która jest w relacji ku-osobowej. Osoba zaś człowieka jako sama w sobie przygodna istotnie dąży cała do spełnienia się w Osobie, w Osobach Bożych.

W temacie wiązania świata i rzeczy z osobą bardzo ciekawa jest dawna nauka wielkich religii; że mianowicie powstają one przez słowo osoby, przez nadanie im imienia przez Boga lub też człowieka. Oto w słynnym poemacie kreacjonistycznym babilońskim z II tys. przed Chr. Enuma elisz czytamy:

Enuma elisz la naba szamamu...

Gdy w górze niebo nie zostało (jeszcze) nazwane, poniżej ziemia nie miała swego imienia...

Nikt nie został nazwany ani nie wyznaczono mu losów wówczas bogowie zostali stworzeni (między wodami) .

$4 \quad$ Por. M. Jędraszewski, Wobec innego, Poznań 1990.

$5 \quad$ Np. Epistula 140, 18 PL. PL 33,545.

$6 \quad$ K. Łyczkowska, Mitologia Mezopotamii, Warszawa 1981, s.198. 
A także na staroegipskim Pomniku teologii memfickiej z tej samej epoki zapisano, że bóg Ptah stworzył świat i człowieka słowem: „Gdy Ptah stworzył wszystkie rzeczy i słowa boże (hieroglify), był bardzo zadowolony”.

Również w odległych Chinach w VI w. przed Chr. Laozi (Lao-tse) w swoim dziele Daodejing (wym. Daodedźing) pisał:

Droga, która może być nazwana, nie jest trwałą drogą,

Imię, które może być przydane, nie jest trwałym imieniem.

Bezimienność była początkiem nieba i ziemi,

Nazywanie dopiero było matką stworzeń ${ }^{8}$.

A nie trzeba nam przypominać Księgi Rodzaju: „Bóg rzekł: niechaj stanie się światłość...I nazwał Bóg światłość dniem” (Rdz 1,3.5). „Przyprowadził Bóg (wszystkie istoty żywe) do człowieka, aby dowiedzieć się, jak on je nazwie. I wszystkie żyjące istoty miały się tak nazywać, jak on je nazwał. Człowiek nadał nazwę wszelkiemu bydłu, wszelkim ptakom powietrznym i dzikim zwierzętom" $(\operatorname{Rd} z 2,19-20)$.

I wreszcie:

Na początku było Słowo,

a Słowo było u Boga,

i Bogiem było Słowo (...)

wszystko przez Nie się stało (J 1,1-3).

I tak rzeczywistość nie jest bezimienna lub bezsensowna, bo wszytko stwarza osoba.

\section{Wymiar moralny}

Jest jeszcze jeden element istotny w osobie, który jest pomijany w jej definicjach, a mianowicie: struktura moralna. Moralność nie jest tylko jakąś przypadłością, zachowaniem zewnętrznej konwencji, czy też tylko jakąś cechą działań. Jest to władza samokształtowania i stanowienia o sobie w zakresie duchowej istotności. Ma więc charakter ontyczny. Dlatego duszę i osobę posiada już embrion, ale dla moralności musi w stanie świadomości podjąć istotną decyzję samaookreślenia się wobec Boga. Taka decyzja jest nieunikniona dla bycia osobą spełnioną ostatecznie. I tak personalizm tłumaczy podział duchów na dobrych i złych. Duchy dobre uznały Boga i odwzajemniły Mu miłość, która spełniła ich osoby, duchy złe odrzuciły miłość Boga i sprzeciwiły się Jego świętości. Dlatego duchy złe pozostały ontycznie osobami, ale z powodu niespełnienia się finalnego stały się moralnymi antyosobami. Z kolei człowiek,

$7 \quad$ H. A. Schlögl, Starożytny Egipt, Warszawa 2009, s. 30.

8 Daodejing, 1,5. 
Adam i Ewa, zostali postawieni przed taką samą próbą personalności. I oni próbę tę przegrali, lecz - jak pisał Orygenes - jako byty ziemskie nie wydali decyzji raz na zawsze, ich życie osobowe, i moralne, tylko osłabło, ale zachowali możność nawracania się i szukania dróg powracania do Boga. Jak jednak fundamentalna decyzja moralna jest dla każdej istoty osobowej konieczna, pokazuje fakt, że i sam Jezus Chrystus w swym człowieczeństwie postanowił przejść na początku swej działalności publicznej przez kuszenie Złego (Mk 1,12-13; Mt 4,1-11; Łk 4,1-13). Nie ma też wątpliwości, że istnieje zbawienie dzieci zmarłych bądź w stanie embrionalnym, bądź nieco później bez osiągnięcia pełnej rozumności czy świadomości, ale żadne zbawienie nie jest mechaniczne i bezosobowe, dlatego w inicjacji do nieba zapewne otrzymają warunki, żeby mogły powiedzieć Chrystusowi, że Go miłują, dobrowolnie i z radością. Bo nie ma żadnej miłości, nawet do Boga, z przymusu. Osoba ludzka w swej istocie musi być wolna moralnie. Zniewolona całkowicie z zewnątrz nie jest osobą. A wreszcie jak istotną komponentą osoby jest moralność, świadczy Sobór Watykański II, który uczy, że zbawią się nawet niewierzący, jeśli „bez własnej winy w ogóle nie doszli jeszcze do wyraźnego poznania Boga, a usiłują, nie bez łaski Bożej, prowadzić uczciwe życie" (Lumen gentium, 16).

Osoba ludzka powołana do istnienia w świecie materialnym w pewien misteryjny sposób transcenduje ten świat już w swojej strukturze i działaniu i żyje, choćby nieraz nieuświadomioną, nostalgią za Osobami Bożymi.

Józef Maria Hoene-Wroński (+ 9.VIII.1853), wielki mesjanista polski z XIX wieku na krótko przed śmiercią wyszeptał: „Boże Wszechmocny!... A ja miałem tyle jeszcze do powiedzenia!". Tak jest chyba też z każdym teologiem.

Słowa kluczowe: osoba, sfery osoby, dusza, osoba społeczna, personalizm.

\section{Bibliografia:}

1. Ingarden R, Spór o istnienie świata, 3 tomy, Kraków - Warszawa 1947-1948, 1981.

2. Jędraszewski M., Wobec innego, Poznań 1990.

3. Laozi (Lao-tse), Daodejing.

4. Łyczkowska K., Mitologia Mezopotamii, Warszawa 1981.

5. Poczobut R., Kategoria osoby w kontekście kogniwistyki, „Ethos” 20(2016) nr 4, s. 133-151.

6. Schlögl H. A., Starożytny Egipt, Warszawa 2009.

7. Trojan M., Na tropie zwierzęcego umystu, Warszawa 2013. 